\title{
Hiden, John, Vahur Made and David J. Smith, eds., The Baltic Question during the Cold War (Abingdon, Oxon: Routledge, 2008), 209p.
}

\author{
大 中 真 \\ （桜美林大学リベラルアーツ学群准教授）
}

ONAKa, Makoto, Ph. D.

Associate Professor, College of Liberal Arts, J. F. Oberlin University

本書は, ラウトリッジ社から逐次刊行されている「冷戦史シリーズ」の一冊である。編者の ジョン・ハイデン（John Hiden）はブラッドフォード大学名誉教授, ヴァフル・マテ（Vahur Made）はタルトゥ大学歴史学部准教授，ディヴィッド・スミス（David J. Smith）はグラスゴー 大学中東欧学部の準教授 (現在は教授) である。編者 3 名を含め合計 11 名の執筆者が全 13 章 を担当しているが，その顔ぶれはイギリスの研究者を中心にフランス，ロシア，エストニア， フィンランド, アメリカ, カナダに広く及んでいる。評者は以前, ブラッドフォード大学の研 究室にハイデン教授を，同じくグラスゴーにスミス準教授を訪ねたことがあり，ここでは単な る書評に留まらず，イギリスにおけるバルト研究にも多少触れたいと思う。

イギリスに打けるバルト諸国研究を学問分野として確立し, 多くの弟子を育てた第一人者が ハイデン教授だと見なしてよいであろう。彼はドィッとバルト地域の現代史を専門領域とする が，特に戦間期のバルト研究に関しては数多くの基本文献ともいえる業績を残している ${ }^{(1)}$ 。 八イデン教授は 1988 年, ブラッドフォード大学にバルト研究機関（The Baltic Research Unit, 通称 BRU）を立ち上げたが，折しもソ連邦崩壊とバルト諸国の独立回復と重なったため, 1980 年代終わりから 90 年代にかけてこの地がイギリスにおけるバルト研究の中心拠点となっ た ${ }^{(2)}$ 。これを発展継承する形で，2003 年にスミス準教授がグラスゴー大学に組織を創設し (The Glasgow Baltic Research Unit, 通称 GBRU)，現在に至るまで非常に活発に活動している ${ }^{(3)}$ 。 二人は学問上の師弟関係にあり，BRU とGBRUは連携を保っている。従って本書は，イギリ スに抢けるバルト研究の最新成果といえるであろう。

「バルト問題 ‘the Baltic Question’」とは何か。19世紀のヨーロッパ国際関係に打ける大きな

(1) 例えば代表作として, The Baltic States and Weimar Ostpolitik, Cambridge: Cambridge University Press, 1987.; Defender of Minorities: Paul Schiemann 1876-1944, London: C. Hurst, 2004.; 編著として, The Baltic in International Relations between the Two World Wars, Stockholm: Almqvist \& Wiksell Internat, 1988.; The Baltic and the Outbreak of the Second World War, Cambridge: Cambridge University Press, 1992.

(2) 興味深いことだが，ブラッドフォードには第二次世界大戦後の亡命エストニア人のコロニーがあり， 現在まで組織が活動している。'Bradford Eesti Kodu Club’<http://www.eestikodu.org.uk/> (accessed $9^{\text {th }}$ March 2009) 因みに，イギリスに拈るエストニア人三大コロニーの所在地は, ブラッドフォード, レスター，それにロンドンである。

(3) 'The Glasgow Baltic Research Unit'<http://www.gla.ac.uk/departments/centralandeasteuropeanstudies/ balticunit/ $>$ (accessed $9^{\text {th }}$ March 2009) 
関心事「東方問題 ‘the Eastern Question’」を彷彿とさせるこの言葉は, 第二次世界大戦と冷戦 によって国際政治の重要問題となった。その論点の一つは, 1940 年 6 月にソ連邦がエストニ ア，ラトヴィア，リトアニアを占領した事実であり，今ひとつはアメリカ国務次官サムナー・ ウェルズが翌 7 月にソヴィエトによる占領を認めないと宣言した事実である。ここにバルト諸 国をめぐる問題は，米ソ両超大国の争点となった。バルト問題への接近方法で伝統的なもの は，国際法学者によるものである。すなわち国際法に照らして，ソヴィエト占領には正当性が 存在するか否かを検討する立場であり，これに加えてアメリカ政府の不承認政策（いわゆるス ティムソン・ドクトリン）の検討，さらに国家主体としての占領前のバルト諸国が占領後も存 在しているのか否かの検討（国家継続性の問題）が問われてきた。国際法学の立場からは，ご く最近に至るまで優れた研究が発表されている。しかし, 法的言説の限界から, 徐々に政治 的，社会的，国際的側面からの考察が出るようになり，本書では国際政治の文脈からバルト問 題を検討するとしている（chapter 1, John Hiden, Vahur Made and David J. Smith, Introduction)。 バルト問題を理解する上で避けて通れないのが，戦間期の独立主権国家時代である。第一次 世界大戦とロシア革命により，エストニア，ラトヴィア，リトアニアはそれぞれ独立を達成し た。1920年代および 30 年代に，イギリス，フランス，ドィツがぞのような対バルト政策を展 開したかを包括的にまとめたのが第 2 章である。イギリスとフランスは安全保障をバルト諸国 に与える意思が極めて消極的であり，主に商業面での利益に関心があったこと，ドィッも同様 に経済面での結びつきを重視して, 独ソ不可侵条約締結の最後の段階までバルトへの領土的野 心を決めかねていたことが説明される（chapter 2, Vahur Made, 'The Baltic states and Europe, 1918-1940’)。

そもそもアメリカがどのよらな対バルト政策を持っていたのか，またソヴィエト＝ロシアと の関係とどう整合性を付けようとしていたのかは，本書の根幹に関わる問題提起である。第 3 章では，パリ講和会議で強硬にバルト諸国の法的承認を拒否したアメリカが如何にして国家承 認に踏み切ったのかを，説得的に描いている。続く第 4 章はウェルズ国務次官が出した不承認 宣言に焦点を当て，宣言に至るローズヴェルト外交の背景を分析している。第 5 章の力点は冷 戦期間に移り，国務省内でバルト問題がどのように処理されていたか，1988 年以降の劇的な 進展に不承認政策がどのような影響を与えたかを叙述している。総じてこの3つの章で, アメ リカの対バルト外交を国際関係の枠組みから理解することができる (chapter 3, Eero Medijainen, 'The USA, Soviet Russia and the Baltic states'; chapter 4, Jonathan L'hommedieu, 'Roosevelt and the dictators'; chapter 5, Paul A. Goble, 'The politics of a principle' )。

第 6 章は一転して, ソ連邦からみた対バルト諸国政策を論じている。1920年にソヴィエト =ロシアがバルト諸国を法的承認してから 1991 年 9 月の独立承認までが，通史的に描かれて いる。ソヴィエトの立場からすると，大戦中はバルト問題は大きな稘案であったが，冷戦中は 核軍縮や地域紛争に比べると「比較的小さな」ものになった。この問題が再び脚光を浴びたの は, ソ連邦側の率先で始まった全欧安保協力会議（CSCE）によって出された1975 年のへル シンキ宣言だといら指摘は, 興味深い。（chapter 6, Konstantin K. Khudoley, 'Soviet foreign policy during the Cold War')。

続いて第 7 章はイギリスとバルトの関係が，第 8 章はフランスとバルトとの関係が説明され る。バルト併合に対する反対の度合いは，アメリカ，イギリス，フランスの順で弱くなるが, これは大戦時の現害政治からすれば当然ともいえる。1940年夏, イギリスは世界でただ一 
国，ナチス=ドイッと対峙していたのであり，ソ連邦との友好関係維持は国家生存に直結し た。この時点でのイギリスの態度は, かなり妥協的であった。しかし冷戦期になると, アメリ カほどではないにしても，1991 年まで不承認政策を貫くこととなる。フランスの立場はさら に弱く，戦勝国として国際連合の常任理事国となるには，ソ連邦の支持が不可欠であった。し かもフランス共産党が非常に大きな政治的影響力を持った状況下では，バルト問題に関しては 「傍観者」となってしまったのもやむを得ない。バルト問題を国際政治の表舞台に引き戻した 点で, 第 8 章の筆者もへルシンキ宣言の重要性を強調している。(chapter 7, Craig Gerrard,

'Britain and the Baltic states'; chapter 8, Suzanne Champonnois, 'French policy towards the Baltic states, 1939-1991' )

西ドイッとバルト問題を詳細に検証したのが第 9 章である。言うまでもなくドイッは，独り 不可侵条約のかつての当事国であり，バルト各民族への道義的責任を負っていた。他方，東西 に分割されたまま講和条約も結ばれていない「ドィッ問題」は，戦後国際社会での法的地位を ぞう確定するかという点でバルト問題と密接に結びついていた。加えて，13 世紀のドィッ人 によるバルト地域への征服植民に端を発する特別な関係が存在する。そして大戦末期に, 敗走 するドイッ軍と共に亡命してきた数多くのバルト諸国民が, 戦後の西ドィッ国内で活発な政治 的活動を行っていた。冷戦下の分断国家という環境の中で，上記に挙げた様々な要因や思惑が 結びつきながら，西ドィッはソ連邦によるバルト併合に対して不承認政策を維持した。歴代の 西ドィッ政権の再統一を目指寸政策と，旧ドィッ帝国領各地からの引揚者が結成した団体との 連関を含みながらバルト問題を論じた第 9 章は, 全編の中でも秀逸な研究であると評者は感じ た (chapter 9, Kristina Spohr Readman, 'West Germany and the Baltic question during the Cold War')。

短いながらも第 10 章は, これまであまり知られてこなかったエストニア亡命政府について 貴重な情報を伝えている。ラトヴィアとリトアニアでは亡命政府設立に至らなかったが，エス トニアでは憲法の規定に則って1953 年にオスロとストックホルムで, それぞれ別に二つの亡 命政府が宣言された。今日でもエストニア大統領府公式ホームページには，後を受けた亡命大 統領代行が法的継続性を 1940 年から 1992 年まで保持したと説明されており，実際にはほとん ぞ名目上の存在に過ぎなかったものの,「象徵」としての亡命政府の意味について問いかけて いる。次の第 11 章では, バルト諸国の外交官や亡命者が, 国際社会でどのようなロビイング 活動を行ったかを紹介している。国連で1966 年以来活動した BATUN（The Baltic Appeal to the United Nations）やCSCE，ヨーロッパ評議会などが事例として取り上げられている（chapter 10, Vahur Made, 'The Estonian Government-in-Exile'; chapter 11, Helen M. Morris and Vahur Made, 'Émigrés, dissidents and international organisations')。

ゴルバチョフ政権による大改革の結果として冷戦が終結し，ついにバルト諸国は独立を回復 する。特に 1989 年から 1991 年に焦点を絞り, 国際関係史の観点からバルト問題の解決を扱っ たのが第 12 章である。第 9 章と同じ筆者によるものだが，ここでも浩瀚な資料をもとに重層 的に経過を描いており, 読み応えのある大部の章となっている。特に，その頃に同時進行して いたドイッ再統一問題（2+4プロセス）と湾岸戦争（ビリニュス血の日曜日事件と同時期） を絡めて俯瞰的に理解する必要性を訴えている点は, 冷戦終結から 20 年が過ぎた現在から振 り返ると，説得力を増す。(chapter 12, Kristina Spohr Readman, 'Between political rhetoric and Realpolitik calculations' ) 
最後に，冷戦が終わり，バルト諸国が再独立したことで本当にバルト問題も終わりを告げた のかを問う第 13 章を迎える。ポスト冷戦時代，ロシアとバルト諸国との間には多くの懸案が 残った。ロシア軍撤退，国境線画定条約，ロシア語系住民，最近ではエストニアのブロンズ兵 士像の移動問題である。バルト問題を突き詰めると 1917 年のボリシェヴィキ革命まで遡らざ るをえず，これは（ヨーロッパの）東西問題であり，また（ヨーロッパにとっての）ロシア問 題でもあると結んでいる（chapter 13, David J. Smith, ‘The end of the “Baltic question” ?’ )。

本書により, 多くのバルト研究者が長年追求してきた問題意識, すなわちバルト問題は, 包 括的かつ概念的に整理されている。バルト問題の出発点である 1940 年の併合をめぐる国際関 係についても，これまでの研究蓄積と合わせて，本書でも新たな事実が明らかとなった。評者 が直接確認したことでもあるが，ロンドン郊外のイギリス国立公文書館に所蔵されているバル 卜諸国関連資料ファイルは，重要なものは 30 年ルールによっても公開されず，冷戦終結宣言 が出された後，1990年になってから初めて閲覧可能となった。こうして，多くの資料が利用 可能となった 1990 年代からバルト研究は隆盛し, 今日に至っている(4)。冒頭で述べたように, 本書はその成果の一つであるが，他方で最終章で問題提起されたように，バルト問題はまだ終 わってはいないと評者も感じている。なぜなら，この問題は単なる地域研究を超えた，普遍的 な価値や概念を内包しているからであり，今後の研究の進展はここにかかっているといえるで あろら。

(4) 世界規模に最も学術的に活発なバルト研究学会で，かつ研究者の知的拠点ともなっているのは, 1968 年にアメリカのメリーランド大学で創設された AABS（The Association for the Advancement of Baltic Studies）であり，その学会誌 Journal of Baltic Studies である。〈http://depts.washington.edu/aabs/〉 (accessed $3^{\text {rd }}$ April 2009) 